\title{
E-commerce Adoption and Analysis of the Popular E-commerce Business Sites in Malaysia
}

Chin Yung Wei*, Intan Syahidah Bt Mohd Fauzi, Thenmoley R, Elhag Siddig Elhag Elhussein, and David Asirvatham

Graduate School of Management, Management and Science University, Malaysia

*Corresponding author: Wei CY, Graduate School of Management, Management and Science University, Malaysia, Tel: +60123380855; E-mail: josie_562000@yahoo.com

Received date: March 10, 2018; Accepted date: April 06, 2018; Published date: April 13, 2018

Copyright: (c) 2018 Wei CY et al. This is an open-access article distributed under the terms of the Creative Commons Attribution License, which permits unrestricted use, distribution, and reproduction in any medium, provided the original author and source are credited.

\begin{abstract}
This article employs an analysis of e-commerce adoption and preferred online e-commerce companies in Malaysia. The objectives of this study are to analyse the application and adoption of e-commerce among Malaysian online users. The study analyses each website attractiveness, preferred websites, acceptance level of users, concerns when conducting online transactions, problems encountered and finally type of products and payment method preferred by online users. Online users or customers are the source of information. This report further understands the issues and risks faced by online shoppers and the strength and weakness faced by e-commerce business entity. In this study the researchers analyzed the data collected from 3 popular website users; Lazada, Mudah.com and 11Street. For data collection, online survey, questionnaire and automated web analysis tools and companies business reports were extracted.
\end{abstract}

Keywords: E-commerce; Business; Market; Management

\section{Introduction}

In These Days electronic commerce has become the most important fundamental in supporting different types of business activities that comes out from the convergence of several information technologies and business practices. Additionally, the e-commerce is seen to be an effective way of business trade, with the existence of the adoption that still not extensive among some reservations of both users and nonusers [1]. In fact, the e-commerce adoption has substantial potential to support the growth of SMEs in developed and developing countries alike [2]. On the other hands, the e-commerce adoption in Malaysia was an issue that had a significant contribution in order to move toward the growth of the country economically as well as the ecommerce platforms were the emerging of the market recently [3].

However, the presence of Web 2.0 is considered as another channel of distribution where it contributes the forming of e-commerce business especially SMEs. although, it was an interesting issue to gain the location which it's still the crucial factor for most of the businesses in promoting products or services in both of physical market or virtual market, and most of the largest organizations are having a noticeable profit more than SMEs in both of their improved sales and costs saving with the adoption of e-commerce in their businesses as well as an additional revenue of a stream part from conducting traditional physical store. In hence, to gain more targeted customers from everywhere, always reachable and easier through the connections of the Web 2.0 [3]. Eventually, the top e-commerce marketplaces in Malaysia such as; Lazada, 11street, and Lelong.my were originated from foreign countries and mainly categorized as developed countries due to the fact that the internet penetration in Malaysia, Singapore, and Vietnam are growing more faster than in the world's average [3].

Finally, this paper discusses the background of this study point and why this particular study of "the electronic commerce adoption and the analysis of the popular electronic commerce business sites in
Malaysia "is gone ahead. The following literature review will discuss about the history of the electronic commerce adoption, and will discuss in details the analysis of the popular electronic commerce business sites in Malaysia.

\section{Literature Review}

\section{Electronic commerce}

The e-commerce is known as the digital channels that include data exchange transaction in between of the businesses and the customer Although, there are different types of e-commerce models which it's named according to the action involved such as the consumer, corporations, or government. Moreover, some authors define the electronic commerce as a transactions and activities that occur on the WEB formally, and it digitally enables commercial transactions between two or more organizations and individuals. Commercial transactions involve the exchange of the value across organizational or individual borders in exchange for goods and services and the exchange value is considered as an important value for understanding the limits of e-commerce.

E-commerce allows clarifying how most of the organizations are developed recently and the adoption of e-commerce in the procedures that have grown significantly to improve the conditions in regards to the presence in the international market and break down barriers and reduce costs by removing intermediaries in the value chain. In the recent study of e-commerce, adoption was indicated that the ecommerce potentially brings significant benefits to SMEs as support. And the structure of the e-commerce has stayed constant over the 10 years ago. Although, the e-commerce businesses were controlled by business-to-business (B2B) sales which it's often handled by the electronic data interchange (EDI).and the value of the e-commerce B2B was approximately around $90 \%$ percent. Social networks and participatory web are also used increasingly to market and sell products online in a way that is best suited to individual users. 
Page 2 of 6

Eventually, the e-commerce was existent in the economic life before the spread of the internet note that the e-commerce has developed the technique into the information technology to accelerate their strong presence in doing business in the real-time and it means that it can give an extreme reduction of intermediaries due to the direct relationship between businesses and consumers. Even though, the transaction costs were reduced and allowed them to enter the global market to offer and demand goods and services, and these were the features that are allowed to the traditional e-commerce.

\section{E-commerce business models}

The conceptualize ideas, business models as an organization which speaks of the constancy of the elements that guarantee competition also involves an investment in the traditional value chain. Definition of customer-focused value, many aspects focus on customer preferences, through highly flexible processes, the client receives the new valuation by the speed of care, personalization, and the relationship between quality and price.

Models on electronic commerce as Tap Scott gives the concept of business-web as a business model whose support is the network and which encompass a need to carry out the environment. Timmers model that focuses on the value chain the company promoting its products and services and the most tangible consumer benefits are lower prices and greater variety best information convenience. The Timmers model has been widely used for the subjects of "Business web" to measure the relationships between companies and consumers.

\section{Business-to-consumer (B2C) E-commerce}

This is the best-known type of electronic commerce where business presence in online sales reaches consumers. This includes the purchase of goods and services retail products and content online, although according to data from international organizations is relatively small. It has grown exponentially and has an extensive international presence by Laudon and Traver. There are seven business models for B2C such as portals, online stores, content providers, brokers' transaction creators market, service providers and community providers.

\section{Business-to-business (B2B)}

The model of business to business (B2B) e-commerce is based on transactions made by companies with other companies and it is the model that represents the largest volume of electronic commerce and this poses to Laudon and Traver a size potentially huge. There are two main business models used in the arena: Net B2B Marketplace, including e-distributors, e-procurement, trade and industry consortia and private industrial networks, including networks of individual companies and whole networks the industry. Helgueros et al. consider the full range of actions that can occur in two organizations, such as purchasing, vendor management, payment management, procurement, and tasks as service and support. This method accounts for $80 \%$ of ecommerce in recent years. Some advantages of this type of electronic commerce are reducing transaction costs and reducing time.

\section{Consumer-to-consumer (C2C)}

This type of e-commerce consumers speak of selling to other consumers usually for online sales through auctions as a first consumer electronic marketplaces or using search engines to easily display a catalogue of goods or services.

\section{E-commerce adoption in Malaysia}

Malaysia has around 22 million dynamic web clients (68 percent of the populace) and another five million are required to go online in the following year. The populace has to a great degree high rates of versatile cell entrance, with almost 150 portable memberships for every 100 individuals. Of these portable supporters, 53 percent utilize cell phones. Malaysia's web-based business laws depend on a blend of the Electronic Commerce Act 2006 and the Electronic Government Activities Act 2007. With the presentation of the Personal Data Protection Act 2010, Malaysia turned into the main ASEAN part nation to pass security enactment. The Electronic Commerce Act 2006 is the key wellspring of electronic trade direction for the private part and contains expansive (innovation nonpartisan) arrangements on electronic marks. Also, Malaysia authorized the Digital Signature Act 1997 which covers advanced marks. The Consumer Protection Act 1999 (CPA) secures purchasers against a scope of out of line hones and implements least item models. In 2007, a change was made to the CPA that extended the extension to cover electronic trade exchanges; and in 2010 another arrangement was presented on the general security prerequisite for administrations and the assurance to shoppers from out of line terms in a standard shape contract.

The Malaysian Communications and Multimedia Commission (MCMC) manage the Information and the Communication ventures. The MCMC additionally issues substance and broadcasting rules. See Multimedia Guidelines and Content Code. The Inland Revenue Board of Malaysia made Guidelines on Taxation for Electronic Commerce. The rules cover the extent of charge, the assessment obligation for business, treatment of server and site and an examination of plans of action. See Guidelines on Taxation of E-commerce. In 2016, the Malaysian Ministry of International Trade and Industry (MITI) propelled another e-commerce Initiative with the objective to bring around 80 percent of little and medium-measure undertakings into the universe of e-commerce and to extend advertise access for in excess of 87 million computerized clients in the ASEAN locale. See e-commerce Initiative 2016. This activity is centred around quickening merchant appropriation of e-commerce, expanding the selection of eProcurement by organizations, lifting non-tax boundaries, (for example, e-satisfaction, cross-fringe, e-Payment, and buyer security), realigning existing monetary motivating forces, making key interests in e-commerce players, and elevating the national brand to help crossoutskirt e-commerce.

The Malaysian Government has sworn not to edit the Internet. There is no confirmation of mechanical Internet sifting in Malaysia. In any case, controls on conventional media overflow to the Internet now and again, prompting self-restriction and infrequent examination of bloggers and online reporters.

In the last decade, the Malaysian government has worked hard to gain their goals to become one of the higher income nations in 2020 through the government's Economic Transformation Program (ETP). Although, many numbers of key services industries have been heavily promoted and subsidized to make this goal become a reality and the ecommerce was one of these services industries.

Moreover, in 2015 the internet penetration was almost $70 \%$ percent and only $5 \%$ percent of Malaysian businesses were having an online presence. Although, most of the leader experts believed that the Malaysian e-commerce market was at an inflection point and it will be experiencing a serious inflation period with the rise of the income, a growth of smartphones and the internet penetration were expected to 
increase the proportion of online retails in Malaysia from $0.5 \%$ percent to $5.0 \%$ percent in 2020 . Even though, this will be an interesting time in order to assess the state of the market in the terms of government initiatives, consumer trends, incumbent players, and opportunities for foreign firms.

\section{Government initiatives}

One of the key Entry Point Projects (EPPs) of the ETP is the 'Virtual Mall' venture, which as per the administration's Performance Management and Delivery Unit (PEMANDU) "expects to develop the web based retail advertise, exploiting higher extra cash of the Malaysian populace, better broadband administrations, and the expansion of cell phones in the nation". This activity is upheld by the National online business Strategic Roadmap, which has six prime objectives:

- Increase vender reception of internet business.

- Accelerate reception of e-acquisition by organizations.

- Remove non-levy boundaries (local e-satisfaction, cross-fringe online business, e-instalment, purchaser security).

- Realign existing monetary impetuses.

- Make vital interests in key internet business firms.

- Promote Malaysian organizations to build cross-fringe internet business.

The internet business showcase in Malaysia is required to develop by 10.8 percent in 2016. With the assistance of Alibaba's Jack Ma as of late delegated Malaysia's Digital Economy Advisor, the administration wants to twofold this development to 20.8 percent by 2020 . Various creative approaches have been pushed by the administration to get this going, including the world's first 'advanced facilitated commerce zone', set to open in March 2017.

\section{Malaysian consumer preferences}

As indicated by a 2016 Bain Brief and Google's Consumer Barometer, 14 million individuals - half of Malaysia's populace - are viewed as 'computerized shoppers', implying that they look into items or administrations on the web. Be that as it may, a test looked at webbased business firms is that exclusive 29 percent of shoppers change over this exploration into an on the web buy. An absence of trust is referred to as the fundamental explanation behind this reluctance, which is additionally featured by the want to pay money down when buying products on the web. The Bain inquire about likewise found that Malaysian buyers' the essential explanation behind acquiring on the web are to exploit items not accessible in the nearby market; curiously, the cost was not recorded as a critical influencer.

Another testing part of the Malaysian web-based business advertising is the inclination towards 'social trade' - the utilization of web-based social networking destinations, for example, Instagram or Facebook, to encourage online exchanges. Bain examine proposes that up to 30 percent of all internet business exchanges in Southeast Asia are 'social deals'. The individual nature of a social deal, in which a buyer associates straightforwardly with a merchant via web-based networking media, dispenses with the absence of assuming that is as yet display for an expansive number of Malaysian customers. The key test for firms, especially originating from abroad, is the manner by which to build up an individual online business methodology. Statista reports that e-travel is the biggest portion of the online business-topurchaser (B2C) advertise in Malaysia.
This fragment incorporates versatility administrations (e.g., ridehailing applications, for example, Grab Taxi) and online travel appointments, and is set to produce over US $\$ 3.5$ billion in income in 2016. The online buy of merchandise will yield a further US\$894 million, with 'Hardware and Media' being the most mainstream classification among Malaysian customers. At long last, eadministrations, counting nourishment conveyance administrations and web-based dating, among others, will include another US $\$ 260$ million. The chart underneath demonstrates the present and expected the size of the fragments in 2021.

As far as online commercial centres for products, the market is exceedingly divided; 10 stages serve around 90 percent of the market (see diagram underneath). The biggest pieces of the overall industry are commanded by neighborhood and provincial players, with worldwide players, for example, Amazon and Group on attempting to pick up the piece of the overall industry. This can be connected to the Malaysian purchasers' want for an individual administration.

As per the Malaysia Digital Economy Corporation (MDEC), the nation's internet business biological system is still in a generally beginning period of improvement. Various elements distinguished by MDEC as keeping down the web-based business advertise in Malaysia incorporate an absence of a supporting biological community, poor satisfaction experience, and low appropriation rates. Despite this, various key players are developing in supporting administrations (e.g., e-instalment and e-fulfillment).IPay88, an online instalment portal, cases to have secured 60 percent piece of the pie of e-instalments. They confront rivalry from MOLPay, GHL e-instalment, and PayPal.

The two pioneers in e-satisfaction are POS Laju, a backup of POS Malaysia postal administrations, and GDex. Littler dispatches, for example, Aramex and Easy Parcel, are likewise going after market share. The lucrative e-travel showcase has high hindrances to section, predominantly because of the nearness of vast territorial and worldwide occupants. Ride-hailing applications, for example, Grab Taxi, BlaBla Car, and Uber have as of late been authorized by the administration and, in that capacity, have fortified their hold and immersed their market. Correspondingly, worldwide travel booking destinations, including Expedia, rule the internet booking market, making it troublesome for new littler players to enter the e-travel battleground.

\section{Identifying opportunities for foreign firms}

Although Malaysia has a generally little populace, its situation at the core of ASEAN (a market of 625 million individuals) and its created foundation makes it an alluring focus for outside firms. The interest of the web-based business industry is helped by the rapid web that achieves very nearly seventy-five percent of the populace, and additionally quick enhancing help administrations and a ready government. Malaysia is additionally a standout amongst the most open economies on the planet, scoring very on both exchanges and venture flexibility on the Economic Freedom Index. Malaysian buyers' want to buy outside products online presents a possibly lucrative chance to remote retailers and wholesalers.

Existing e-commercial centres offer a strong stage from which to infiltrate the market. When entering the Malaysian market, it is critical to do broad research before picking a nearby accomplice; enhancement of accomplices may ease hazard in the developing online business ecosystem. Further government motivations and expanded appropriation are required to draw ventures from worldwide players 
who would prefer not to pass up a great opportunity for Malaysia's approaching internet business blast. The additional venture will encourage the advancement of the business and its supporting administrations, additionally expanding its engaging quality to new participants. With 2017 touted to be 'the time of the Internet Economy', it will enthusiasm to see whether the Malaysian web-based business industry can satisfy the buildup.

\section{Current market trends}

As of Malaysia's web and versatile availability, and in addition open segment consolation, Malaysia has high rates of e-commerce use. Malaysia gloats 15.3 million online customers (50 percent of the populace) and 62 percent of portable clients their gadgets to shop on the web. Online customers are inspired by value points of interest, item range, and accessibility of surveys. Malaysian customers search with the expectation of complimentary transportation, comfort, and elite arrangements offered by online stores.

\section{Web-based shopping patterns}

\section{Top 3 divisions utilizing web-based shopping are}

- Design and Accessories - 16 percent

- Home and Living - 15 percent

- Wellbeing and Beauty - 13 percent.

\section{Developing recurrence of shopping online}

- 30 percent once every month

- 15 percent once at regular intervals

- 14 percent once every week or all the more regularly

- 80 percent of Malaysian online customers are utilizing their cell phones.

- 54 percent like to pay utilizing on the web exchange (12 percent money down, 1 percent paid ahead of time to account, 33 percent credit/charge card).

- Travel installment is required to develop to USD $\$ 4.41$ billion/RM 19.6 billion worth of online exchanges in 2017.

- Items just online deal volume will develop to USD \$1.12 billion/ RM4.99 billion of every 2017, a 20 percent offer of aggregate internet business advertise measure in Malaysia.

\section{Patterns of the Malaysia online business for in 2017}

- Web-based shopping is situated to continue developing.

- Installment strategies will turn out to be more advanced.

- Clients will shop new items classes.

- Expedited service will turn into the standard.

- Clients will look priceless.

\section{An overview of the popular E-commerce business sites in Malaysia}

With its dynamic economy and created foundations for computerized advancements, Malaysia is an exceptionally alluring business sector for internet business in Southeast Asia. A few sites and advanced applications are as of now show in the Malaysian internet business scene, with some worldwide, local and national players snatching their offers Entrenched as a standout amongst the unique computerized environments in Southeast Asia, the Malaysian internet business advertising is developing quickly. It is becoming both as far as scale and extension: deals volumes and quantities of online customers and in addition regarding classes of items being purchased on the web.

Despite the fact that driving performers are now set up, new national and outside organizations are pushing their way into Malaysia's appealing business sector. The opposition is likewise ending up more granular, as anybody would now be able to dispatch his own shop on account of the modest web-based business innovation norms: self-facilitated WordPress shop or cloud-facilitated Shopify store that doesn't require any coding ability or configuration encounter. Worldwide, provincial and national online business sites have effectively taken the lion's offer of the Malaysian market. However, with quickly developing volumes, current performing artists and newcomers can at present change the powers of nearness as there is still space for development to achieve Malaysia's aggregate populace of 31 million. Eventually, this outline would give an eye to three business destinations which it's: Lazada, 11street, and Lelong.my.

\section{Lazada}

\section{Monthly Traffic Estimate (Jun 2017): 30,300,000.}

Lazada is a privately owned German e-commerce company, was launched in 2012 by a company known as Rocket Internet based in Singapore, and The purpose of establishing Lazada Group was to exploit the online consumer market niche in Southeast Asia similar to the one served by Amazon.com in other parts of the world. Additionally, Lazada operates in Indonesia, Malaysia, Philippines, Thailand, and Vietnam. Lazada raised its capital via aggressive funding drives and by 2014, had lured in notable investors such as JP Morgan, Swedish retail giant Kinnevik, and German equity firm Summit Partners, Tesco, Temasek Holdings, Access Industries Tengelmann and Rocket Internet. Although, they managed to raise an unprecedented $\$ 647$ Million (US), and in a formative stage they sold goods purely from their own warehouses to diversify its portfolio.

\section{1 street}

Monthly Traffic Estimate (Jun 2017): 10,200,000

11Street is an open marketplace operated by Celcom Planet Sdn. Bhd. Although, it is considered as one of the largest e-commerce companies established in Malaysia, and It was originally leading ecommerce company in South Korea, operating under the management of SK Planet Co. 11Street expanded its operations to Malaysia to grow and expand the E-Commerce industry in the country, and they are currently operating from their main office located in Kuala Lumpur Sentral since January 2015. 11Street has over 400,000 sellers, serving over 30 million customers and with US\$6 billion gross merchandising value. Additionally, 11street has also expanded its operations to Turkey in 2012 and Indonesia in 2014. Moreover, Celcom Planet Sdn Bhd (also known as 11Street Malaysia) was established in November 2014 as a joint venture company between Celcom Axiata Berhad (49\%) and SK Planet Ltd (51\%).

\section{Lelong.my}

\section{Monthly Traffic Estimate (Jun 2017): 6,200,000}

Lelong is an online auction and trading website founded by Internet base Resources Sdn. Bhd at 1998. Although, they are considered as the pioneer of e-auction in Malaysia, and their mission statement is serving the community and bringing a high standard of quality into 
Page 5 of 6

homes and businesses by providing an avenue for online trading at a low cost. As compared to the international auction website- ebay.com, Lelong has more public awareness in local rather than internationally. Lelong has a growing amount of users, most users sell their used items through Lelong, and there are quite a few store sellers as well. Lelong.com.my powers a robust and secure avenue for trading in Malaysia. Lelong.com.my is provided many products and services to the public such as clothing and accessories, books and comics, watches, pens, and clocks with the entire picture. And each product started with a standard price. Besides, Lelong.com.my also provides the search engine to ease the consumer faster to search their needs with the keywords.

\section{Conclusion}

This paper is be focusing on a discussion of the literary works of various scholars investigating the e-commerce adoption and the analysis of the popular e-commerce business sites in Malaysia, and The literature reviewed to identify the e-commerce, the e-commerce business models, the e-commerce adoption in Malaysia, current market trends, and an overview of the popular e-commerce business sites in Malaysia.

\section{Methodology}

\section{Sampling technique}

The target population of this study is the people with Malaysian nationality and living in Malaysia. By 1st January of 2018, it is said that there are 31,505,208 people in Malaysia (Malaysia Population Clock). Therefore, it is difficult to establish the sample size for this study. Due to the large number of population in Malaysia, the convenience sampling technique was adopted. The sampling technique allows the collection of data to be carried out conveniently from the members of the population.

\section{Data collection and instrumentation}

Data collection for the survey is carried out through an online questionnaire administered through online Google Form. The link of the online survey form was administered through e-mails and social media. Cross-sectional study was used to collect the data for this study.

The questionnaire was divided into four (4) sections. Section one identified the application and adoption of e-commerce among Malaysians based on the frequency, purpose, preferred commercial transactions, preferred e-commerce website, preferred payment method and website attractiveness. Section two is aimed in identifying the issues and risks faced by e-commerce users during online purchasing and online payment transactions. The third section of the questionnaire establishes the basic knowledge of Malaysians regarding e-commerce. This section consisted of questions on the advantages and challenges of e-commerce on businesses, and also on opinions regarding the future of e-commerce. The fourth section of the questionnaire establishes users' demographic in terms of average income and age group.

\section{Results and Analysis}

Based on the survey, more than half of respondents which is $55 \%$, bought products or services online once in a month. The outlook for online purchases is shown positive despite the economic recession [4]. To examine Malaysian spending behaviour on e-commerce, Table 1 shows percentage of transaction types done over e-commerce.

\begin{tabular}{|l|l|l|l|l|}
\hline No. of Respondents & $\begin{array}{l}\text { E-commerce for Business } \\
\text { Use }\end{array}$ & $\begin{array}{l}\text { E-commerce for Personal } \\
\text { Use }\end{array}$ & $\begin{array}{l}\text { E-commerce for Business and Personal } \\
\text { Use }\end{array}$ & $\begin{array}{l}\text { E-commerce for Others } \\
\text { Use }\end{array}$ \\
\hline 100 & $4 \%$ & $60 \%$ & $27 \%$ & $9 \%$ \\
\hline
\end{tabular}

Table 1: Percentage of transaction types done over e-commerce.

The top 3 e-commerce websites most frequently visited by the respondents are Lazada (71\%); Others (43\%); Mudah.com (31\%). From the finding, Malaysian users prefer an e-commerce marketplace such as Lazada and Mudah.com where product or service information is provided by multiple third parties. On the other hand, $43 \%$ online shoppers prefer other websites which are not detailed in the survey. We can see that Malaysian e-commerce website has grown to support various types of payment methods which are detailed in Table 2 .

\begin{tabular}{|l|l|l|l|l|l|}
\hline No. of Respondents & Credit Card & Debit Card & Online Banking & Paypal & Others \\
\hline 100 & $36 \%$ & $18 \%$ & $35 \%$ & $5 \%$ & $6 \%$ \\
\hline
\end{tabular}

Table 2: Malaysian e-commerce website has grown to support various types of payment methods.

\begin{tabular}{|l|l|l|l|l|l|}
\hline No. of Respondents & Product Quality Uncertain & Delivery Time Frame & Warranty or Guarantee offered & Network Problem & Others \\
\hline 100 & $52 \%$ & $21 \%$ & $14 \%$ & $7 \%$ & $6 \%$ \\
\hline
\end{tabular}

Table 3: The major issue faced by e-commerce users.

$41 \%$ of respondents like to shop online due to its convenience, whereas $29 \%$ due to attractive offers and $21 \%$ due to availability of price comparison. This finding aligned with Shanthi and Kannaiah where they revealed one of the major factors that consumers chose to shop online as it due convenience in nature and as it saves lot of time 
and effort as compared to the real time shopping [5]. The major issue faced by e-commerce users are stated in Table 3 .

We could clearly see that the main difficulty that e-commerce users faced is the product quality uncertainty, which made up 52\% of total respondents. Furthermore, $58 \%$ of survey participants think the biggest challenge to the implementation of e-commerce in Malaysia is security and privacy concerns [6]. 41\% revealed that they are taking the risk about personal information confidentiality when executing online transactions; only 7 out of 100 respondents reported that they show high confidence in this area. According to Khatibi, doubt on security and privacy is one of the barriers faced by Malaysian ecommerce businesses besides stringent requirement on technology and uncertainty of rules and regulation.

The demographic of respondents showed that the age group between 20 to 29 years are the highest age group that used e-commerce i.e., $42 \%$. Therefore, we could disclose that age group between 21 to 29 years has higher correlation in online transactions as compared to other age group. In terms of average income, majority of respondents (44\%) fall under the below RM36,000 per annum category [7].

Large majority of the survey respondents show positive view for the future and adaptation of e-commerce in Malaysia [8-10]. This finding aligns with the website evaluation done on 3 main e-commerce sites in the country i.e., Lazada, 11Street and Lelong. All these 3 websites scored 5.75 points or above on a 10 points scale. We can see that the quality of these e-commerce web pages in terms of functionality, authority and attractiveness manage to meet consumers' expectation however there is room for improvements [11-16]. Based on the web analysis done by Woorank and SEO SiteCheckup, some of the suggested improvements include use of keywords and site internal navigation and links optimization.

\section{Discussion and Conclusion}

From the finding, it was found that Malaysians prefers an ecommerce marketplace such as Lazada, Mudah.com and 11Street where online shoppers are able to purchase product and service. This is due to the fact that information are provided by multiple third parties or business entities for shoppers immediate decision making. Moreover, we can see that Malaysian e-commerce website has grown rapidly to support various types of payment methods such as credit card, debit card, PayPal and online transactions. The survey further revealed one of the major reasons consumers choose to shop online is due to convenience as it saves time and effort as compared to the real time shopping experiences.

Major issues faced by e-commerce users are the product quality uncertainty. Moreover, the survey participants think the biggest challenge to the implementation of e-commerce in Malaysia is security and privacy concerns. As online shoppers feels that they are taking risk in revealing their personal confidential information when executing online transactions; doubt on security and privacy is one of the barriers faced by Malaysian e-commerce businesses besides stringent requirement on technology requirement and the investment on it. Beside this the need to comply and adopt to the constant evolving of rules and regulation that governing the e-commerce industries are seen as one of a major setback to this industry.

However, majority of respondents gave positive review for the future and adaptation of e-commerce in Malaysia. Literally, with improvements in the quality of e-commerce web pages in terms of functionality, authority and attractiveness the e-commerce industry may emerge to meet or exceed online shoppers' expectation. Based on the report, some of the suggested improvements include the use of keywords and site internal navigation and links optimization to enhance its features and drive more traffic to the websites.

\section{References}

1. Sulaiman A, Jani R, Bahri S (2001) The Development of E-commerce in Malaysia. In Towards the E-Society 74: 341-353.

2. Kurnia S, Choudrie J, Mahbubur RM, Alzougool B (2015) E-commerce technology adoption: A Malaysian grocery SME retail sector study. Journal of Business Research 68: 1906-1918.

3. Ismail AF, Tean WS, Sam MFM, Pei CS (2017) E-Commerce Adoption among Retailing Malaysia's SMEs in Perspective of TechnologicalOrganizational-Environmental (TOE) Framework. International Journal of Economics, Commerce and Management.

4. Kaur M (2016) Recession in Malaysia in 2018, predicts expert.

5. Shanthi R, Kannaiah D (2015) Consumers' Perception on Online Shopping. Journal of Marketing and Consumer Research.

6. Vargas-Hernández JG (2015) Strategies for the Adoption of E-commerce. Journal of Global Economics 3: 157.

7. Handley H (2016) An Introduction to e-Commerce in Malaysia.

8. Ben-Menachem M (2018) A Business Model for Hydrogen Fuel and Hydrogen Cars Infrastructure. J Bus Fin Aff 7:313.

9. Haynes TE (2018) Exploring Strategies Microenterprise Owners use to Succeed in Business Beyond 2 Years. J Bus Fin Aff 7:312.

10. Sanidas E (2018) The Role of Knowledge in Determining Innovations, Technology, Business, Management and Economic Development: An Expansion Beyond Knowledge. Int J Econ Manag Sci 7: 501.

11. Atif M (2018) An Enhanced Framework for Sentiment Analysis of Students' Surveys: Arab Open University Business Program Courses Case Study. Bus Eco J 8: 337.

12. Ayob F (2016) Evaluating Websites of Small-and-Medium-Sized-Hotels (SMHs): A StagesModel of E-Commerce Websites Adoption for Malaysian Hotels. J Hotel Bus Manage 5:149.

13. Kiang YJ (2016) An Empirical Study of Customer Value, Customer Trust and Customer Loyalty Based on E-Commerce. Bus Eco J 7: 242.

14. Haron AJ (2016) E-Commerce Innovations Customer Perceptions in Qatar. Int J Econ Manag Sci 4: 310.

15. Vargas-Hernández JG (2015) Strategies for the Adoption of Ecommerce. J Glob Econ 3: 157.

16. Morris B and Behzad F (2014) The Effects of Gold and Silver Nanoparticles on an Enzymatic Reaction Between Horseradish Peroxidase and 3,3',5,5'-Tetramethylbenzidine. Biochem Pharmacol (Los Angel) 3: 146 . 